\title{
Germination and seedling establishment of spiny hopsage in response to planting date and seed- bed environment
}

\author{
NANCY L. SHAW, MARSHALL R. HAFERKAMP, AND EMERENCIANA G. HURD
}

\begin{abstract}
Shaw and Hurd are botanists, USDA Forest Service, Intermountain Research Station, Forestry Sciences Laboratory, Boise, Ida. 83702; Haferkamp is range scientist, USDA-ARS, Fort Keogh Livestock and Range Research Laboratory, Miles City, Mont. 59301.
\end{abstract}

\begin{abstract}
Reestablishment of spiny hopsage (Grayia spinosa [Hook.] Moq.) in the shrub steppe requires development of appropriate seeding technology. We examined the effect of planting date and seedbed environment on germination and seedling establishment of 2 seed sources at 2 southwestern Idaho sites. Seedbeds were prepared by rototilling. In 1987-88, seeds collected in 1986 were drilled at 66 viable seeds $\mathrm{m}^{-1}$ of row at Birds of Prey in late fall, winter, and early spring and at Reynolds Creek in late fall, early spring, and late spring. Seeds collected in 1986 and 1988 were broadcast at 400 viable seeds $\mathrm{m}^{-2}$ at both sites in late fall, early spring, and late spring 1988-89. Seeds in nylon bags were also planted at each site in late fall, winter, and early spring in 1987-88 and in late fall, winter, early spring, and late spring in 1988-89. On each succeeding planting date and in early summer, 5 bags of each seed source from each of the earlier planting dates were recovered. Water content, viability, and germination were compared among seeds from previous plantings and control seeds stored in the laboratory. Each year, first-year seedling establishment at both sites was favored by late fall compared to other planting dates. In 1988, seedlings established only from late fall plantings at a density of $1 \mathrm{~m}^{-2}$ at each site. In 1989, late fall planting at the 2 sites increased seedling establishment $6\left(51 \mathrm{vs} 8 \mathrm{~m}^{-2}\right)$ and $20\left(41 \mathrm{vs} 2 \mathrm{~m}^{-2}\right.$ ) times compared to early spring planting. Germination was generally greater for seeds incubated at field sites compared to controls. Germination total and rate increased 6-11 times and 13 days from late fall 1987 to early spring 1988, 1-6 times and 4 and 9 days from winter 1988 to early spring 1988, 17 times and 10-11 days from late fall 1988 to winter 1989, and 4-7 times and 11 days from winter 1989 to early spring 1989. Late fall or early winter planting is essential to permit early spring germination when surface soils are moist.
\end{abstract}

Key Words: chenopod shrubs, Grayia spinosa, revegetation, seedbed ecology, shrub steppe

Spiny hopsage (Grayia spinosa [Hook.] Moq.), a summerdeciduous shrub, is an endemic chenopod of the interior western United States. It commonly occurs in drier portions of Wyoming big sagebrush (Artemisia tridentata Nutt. ssp. wyomingensis [Beetle and A. Young] Welsh) communities and in a variety of salt desert shrub communities (Daubenmire 1978, Blaisdell and Holmgren 1984). Spiny hopsage is often heavily grazed by livestock in spring and in some areas is being replaced by less palatable species

The authors express appreciation to John Kinney for field assistance; Consuelo Solis for assistance with graphics; and the USDI Department of Interior, Bureau of Land Management, Boise District, for providing study sites.

Manuscript accepted 6 Nov. 1993.
(Blaisdell and Holmgren 1984). Local populations have been destroyed or damaged by wildfires and drastic disturbances associated with human activities (Wallace and Romney 1972, Rickard and McShane 1984). Reestablishment of the species is desirable to increase native plant diversity on disturbed sites and provide forage, cover, and soil stabilization (USDA-SCS 1968, McCullough 1969, Krysl et al. 1984).

Requirements for germination and seedling establishment of Nevada and California spiny hopsage populations producing nondormant seeds were examined by Wood et al. (1976), Ackerman (1979), Beatley (1979/80), and Manning and Groeneveld (1990). Requirements for northern populations, however, are poorly understood. Glazebrook (1941) found seeds of an eastern Washington population were nondormant, while King (1947) reported seeds from the same area required moist prechilling to germinate. Recommended planting dates are early spring or late fall for eastern Washington (Glazebrook 1941) and late fall or early winter for southern Idaho (Shaw and Haferkamp 1990). The small seeds (869-932 $\mathrm{g}^{-1}$ ) require shallow planting (Smith 1974, Wood et al. 1976).

Fall or winter planting naturally provides cool-moist seedbed environments. Seeds planted near the soil surface, however, are subjected to extremes of water and temperature conditions that may decrease vigor. More information on the effects of seedbed environments on seed germination and seedling establishment is needed to develop seeding strategies and techniques to maximize returns from field or nursery seedings. The objective of this study was to determine the effects of planting date and microenvironmental conditions on seed germination and seedling establishment of 1 southwestern Idaho and 1 southeastern Oregon spiny hopsage population at 2 southwestern Idaho sites.

\section{Materials and Methods}

\section{Seed Collections}

Mature utricles enclosed within the papery bracts were harvested in June 1986 and 1988 at Sponge Springs (Sponge Springs 1986 and Sponge Springs 1988 seed lots), Malheur Co., Oregon $\left(43^{\circ} 48 \mathrm{~N} 117^{\circ} 26^{\prime} \mathrm{W}\right)$ and at Reynolds Creek, Owyhee Co., Idaho $\left(43^{\circ} 16^{\prime} \mathrm{N} 116^{\circ} 43^{\prime} \mathrm{W}\right.$ ) (Table 1$)$. Utricles were collected from 2 Reynolds Creek sites about $1 \mathrm{~km}$ apart in June 1986 (Reynolds 1986A and Reynolds 1986B seed lots). Only the Reynolds 1986B site produced adequate quantities of utricles for harvest in June 1988. Collections were air-dried for 2-4 weeks and stored in the laboratory. Seeds were removed from utricles to simplify handling and planting. This approach was justified as Wood et al. (1976) reported similar seedling establishment from seeds and utricles planted 5-mm deep in a greenhouse study. Utricles were threshed 
Table 1. Characteristics of spiny hopsage seed collection sites.

\begin{tabular}{|c|c|c|}
\hline & Sponge Springs & Reynolds A and B \\
\hline Location & $\begin{array}{l}\text { Malheur Basin, } \\
\text { southeastem Oregon }\end{array}$ & $\begin{array}{l}\text { Northern foothills } \\
\text { of Owyhee Mountains, } \\
\text { southwestern Idaho }\end{array}$ \\
\hline Vegetation & $\begin{array}{l}\text { Artemisia tridentata } \\
\text { ssp. wyomingensis, } \\
\text { Sarcobatus vermiculatus } \\
\text { (Hook.) Torr., Grayia } \\
\text { spinosa, Bromus } \\
\text { tectorum L. }\end{array}$ & $\begin{array}{l}\text { Artemisia tridentata } \\
\text { ssp. wyomingensis, } \\
\text { Sarcobatus vermiculatus, } \\
\text { Grayia spinosa, Elymus } \\
\text { elymoides (Raf.) Swezey, } \\
\text { Bromus tectorum }\end{array}$ \\
\hline Elevation (m) & 991 & 1,260 \\
\hline $\begin{array}{l}\text { Precipitation } \\
\quad(\mathrm{mm})\end{array}$ & $228^{1}$ & $249^{2}$ \\
\hline Soil & $\begin{array}{l}\text { Fine-loamy, mixed mesic } \\
\text { Xerollic Durargids }{ }^{3}\end{array}$ & $\begin{array}{l}\text { Lolalita Series. Coarse- } \\
\text { loamy, mixed nonacid, } \\
\text { mesic, Xeric } \\
\text { Torriorthents }\end{array}$ \\
\hline
\end{tabular}

J.M. Findley (unpublished data).

${ }^{2}$ C.L. Hanson (unpublished data).

3Oregon Water Resources Board (1969).

${ }^{4}$ Stephenson (1977).

using a mechanical seed scarifier (Shaw and Haferkamp 1990).

Chaff was removed with an air-screen cleaner and a seed blower.

Threshed seeds were stored in plastic containers at $3-5^{\circ} \mathrm{C}$. Water contents ranged from 6 to $10 \%$.

\section{Planting Sites}

Field plantings were made in southwestern Idaho at Birds of Prey $\left(43^{\circ} 18 \mathrm{~N} 116^{\circ} 22^{\prime} \mathrm{W}\right)$ and Reynolds Creek $\left(43^{\circ} 13 \mathrm{~N} 116^{\circ} 44^{\prime} \mathrm{W}\right)$

Table 2. Characteristics of spiny hopsage planting sites, southwestern Idaho.

\begin{tabular}{|c|c|c|}
\hline & Birds of Prey & Reynolds Creek \\
\hline Location & $\begin{array}{l}\text { Lower Snake River } \\
\text { Plains, southwestern } \\
\text { Idaho }\end{array}$ & $\begin{array}{l}\text { Northern foothills } \\
\text { of Owyhee Mountains, } \\
\text { southwestern Idaho }\end{array}$ \\
\hline Vegetation & $\begin{array}{l}\text { Artemisia tridentata } \\
\text { ssp. wyomingensis, } \\
\text { Ceratoides lanata } \\
\text { (Pursh) J.T. Howell, } \\
\text { Grayia spinosa, Poa } \\
\text { secunda Presl, Elymus } \\
\text { elymoides, Salsola } \\
\text { iberica Sennen \& Pau }\end{array}$ & $\begin{array}{l}\text { Artemisia tridentata } \\
\text { ssp. wyomingensis, } \\
\text { Atriplex confertifolia } \\
\text { (Torr. \& Frem.) Wats, } \\
\text { Grayia spinosa, Elymus } \\
\text { elymoides, Lepidium } \\
\text { perfoliatum L., Salsola } \\
\text { iberica }\end{array}$ \\
\hline Elevation (m) & 85 & 1,200 \\
\hline $\begin{array}{l}\text { Mean annual } \\
\text { precipitation } \\
\text { and distribution }\end{array}$ & $\begin{array}{l}248(56 \% \text { from } \\
\text { Oct.-Mar.) }\end{array}$ & $\begin{array}{l}234 \text { ( } 54 \% \text { from Oct.-Mar., } \\
20 \% \text { as snow) })^{2,3}\end{array}$ \\
\hline $\begin{array}{l}\text { Mean annual } \\
\text { temperature } \\
\text { and range }\left({ }^{\circ} \mathrm{C}\right)\end{array}$ & $\begin{array}{l}11,-2 \text { (Jan.) to } \\
21 \text { (Jul.) }\end{array}$ & $\begin{array}{l}8,-2 \text { (Jan.) to } \\
20(\text { Jul. })^{2}\end{array}$ \\
\hline $\begin{array}{l}\text { Mean annual } \\
\text { frost-free days }\end{array}$ & $150^{4}$ & $90-100^{3}$ \\
\hline Soil & $\begin{array}{l}\text { Scism Series. Well- } \\
\text { drained silty mixed mesic } \\
\text { Haplo Xerollic Durorthids } \\
\text { formed over loess on } \\
\text { a basalt plain. Hardpan } \\
\text { at } 0.5-1.0 \mathrm{~m}^{4}\end{array}$ & $\begin{array}{l}\text { Nannyton Series. Fine } \\
\text { loamy mixed mesic Typic } \\
\text { Haplargids derived from } \\
\text { granitic, basaltic, and } \\
\text { rhyolitic alluvium }{ }^{3}\end{array}$ \\
\hline
\end{tabular}

${ }^{1}$ Kuna 2 Weather Station, approximately $20 \mathrm{~km}$ northwest of the planting site (NOAA 1987-89).

2 Hanson (unpublished data)

${ }^{3}$ Stephenson (1977).

${ }^{4}$ Collett (1980)
(Table 2). The Reynolds Creek site is about $2.5 \mathrm{~km}$ south of the Reynolds A and B seed collection sites.

Precipitation was measured continuously at both sites. Air temperature was measured continuously at the Birds of Prey site and at the Reynolds Weather Station $3 \mathrm{~km}$ south of the Reynolds Creek planting site (NOAA 1987-89). Soil water content for the 0-30 mm depth was determined gravimetrically on selected dates. Soil water retention curves developed for $0.0,-0.01,-0.08,-0.20$, and $-1.50 \mathrm{MPa}$ at the 2 sites corresponded to $28.9,21.0,7.9,6.6$, and $6.2 \%$ soil water at Birds of Prey and 22.7, 18.6, 12.1, 9.5, and $5.2 \%$ soil water at Reynolds Creek. Soil temperature $(0-20-\mathrm{mm}$ depth) was measured using recording soil thermographs.

\section{Seedbed Preparation and Stand Evaluation $1987-1988$}

Seedbeds were prepared by twice-over rototilling to a depth of about $15 \mathrm{~cm}$ in fall. Residual rootcrowns of shrubs and perennial grasses were removed manually. Surfaces of the $3.0-$ by $1.5-\mathrm{m}$ plots were hand raked just prior to seeding.

Five rows, $3 \mathrm{~m}$ long and $0.3 \mathrm{~m}$ apart, were planted in each plot using a single-row cone seeder equipped with a double-disk opener and rubber packer wheel. Viable seeds were planted about $5 \mathrm{~mm}$ deep at a rate of $66 \mathrm{~m}^{-1}$ of row $\left(217 \mathrm{~m}^{-2}\right)$. Viability of each seed source was evaluated by tetrazolium staining (AOSA 1970). Seed sources (Sponge Springs 1986 and Reynolds 1986A) and planting dates (Table 3) were arranged in a randomized-complete-block

Table 3. Planting ${ }^{1}$ and seed recovery dates for spiny hopsage at Reynolds Creek and Birds of Prey planting sites, southwestern Idaho, 1987-88 and 1988-89. Seeds were planted in nylon mesh bags and direct seeded in small plots.

\begin{tabular}{llll}
\hline \hline $\begin{array}{l}\text { Planting/ } \\
\text { recovery date }\end{array}$ & Year & $\begin{array}{l}\text { Birds of } \\
\text { Prey }\end{array}$ & $\begin{array}{l}\text { Reynolds } \\
\text { Creek }\end{array}$ \\
\hline Late fall ${ }^{2}$ & $1987-88$ & Dec. 17 & Dec. 7 \\
& $1988-89$ & Dec. 21 & Dec. 9 \\
Winter & $1987-88$ & Jan. 26 & Jan. 31 \\
& $1988-89$ & Feb. 13 & Jan. 273 \\
Early spring & $1987-88$ & Feb. 19 & Feb. 21 \\
& $1988-89$ & Mar. 1 & Feb. 27 \\
Late spring & $1987-88$ & Mar. 114 & Mar. 134 \\
& $1988-89$ & Mar. 23 & Mar. 20 \\
Early summer & $1987-88$ & May 3 & May 4 \\
& $1988-89$ & May 8 & May 10 \\
\hline
\end{tabular}

ISeed sources: Reynolds, site A, and Sponge Springs 1986 collections planted in 1987 -88. Reynolds, site B, and Sponge Springs 1986 and 1988 collections planted in 1988-89.

2Planting only.

${ }_{3}$ Nylon mesh bags, but not small plots planted due to adverse weather conditions. ${ }^{4}$ Small plots, but not nylon mesh bags planted.

${ }^{4}$ Small plots, but
${ }^{5}$ Recovery only.

design with 4 blocks. Seedling density was estimated by counting seedlings in a 2-m row segment in each of the 3 inside rows in each plot. Density was estimated at Birds of Prey on 19 April, 20 May, and 27 June 1988 and 21 July 1989, and at Reynolds Creek on 19 April, 26 May, and 24 June 1988 and 11 July 1989. Height of all seedlings was determined on the 1989 counting dates.

\section{$1988-1989$}

Seedbeds were prepared as in 1987. Seeds were broadcast instead of drilled because of limited seed supplies. Plots $0.25-\mathrm{m}^{2}$ were broadcast at a rate of 400 viable seeds $\mathrm{m}^{-2}$, covered with about $5 \mathrm{~mm}$ of soil, and compacted lightly. Seed sources (Sponge Springs 1986, Sponge Springs 1988, Reynolds 1986B, and Reynolds 1988B) and planting dates (Table 3) were arranged in a randomized-complete-block design with 10 blocks. Seedling density was estimated by counting all seedlings in each plot. Counts were 
made at Birds of Prey on 12 March, 23 March, 18 April, and 6 July 1989 and 17 July 1990 and at Reynolds Creek on 11 March, 20 March, 11 April, and 3 July 1989 and 10 July 1990. Height of all seedlings was measured on the 1990 counting dates.

\section{Seed Dynamics}

On each planting date (Table 3 ) nylon bags ( $1-\mathrm{mm}^{2}$ mesh) each containing $3 \mathrm{~g}$ of seeds were placed along the edge of plots planted with the same seed source at each site. Bags were carefully covered with about $5 \mathrm{~mm}$ of soil to simulate direct seeding. We recognize, however, that hand compacting the soil, restricting large quantities of seeds into a small area, and permeability characteristics of the nylon bags may have produced different microenvironmental conditions than drilling or broadcasting.

On the second, third, and fourth planting dates and in early summer, 5 bags of each seed source planted in the field on each of the previous planting dates for that year were recovered (Table 3). Collected bags were returned to the laboratory for immediate processing. Samples were sieved, if necessary, to remove soil and seedlings.

On each collection date, comparisons were made among characteristics of seeds from previous plantings and control seeds stored in the laboratory. To reduce complications in interpretation, comparisons of seed characteristics were made only for collections in which no or very few seeds had initiated germination in the field. The presence of germinating seeds produced a tangled mass of seedlings and empty seed coats, making separation of ungerminated seeds and accurate determination of the field germination percentage extremely difficult.

Subsamples were randomly selected from each bag for determination of water content (about $1.5 \mathrm{~g}$ ), viability ( 50 seeds), and germination ( 50 seeds). On each recovery date, 5 subsamples were also randomly selected from each control for determination of each seed characteristic. In addition, water content of fully imbibed controls was measured in January 1989. Water content was determined gravimetrically by drying seeds for 24 hours at $100^{\circ} \mathrm{C}$.

Germination trials were conducted by placing seeds on 2 blue blotters moistened with distilled water in 110-by 110-mm germination boxes. All seeds were dusted with tetramethylthiuram disulfide to control fungal development. Seeds were incubated for 30 days at $15^{\circ} \mathrm{C}$ with 8 hours of exposure to cool-white fluorescent light (PAR $=15 \mu \mathrm{Mm}^{-2} \mathrm{~s}^{-1}$ ) alternating with 16 hours of darkness. Germination boxes were randomly arranged in the germinator and rerandomized after each count. Germination counts were made at 2-day intervals. Seedlings were considered normal if all structures essential for development were present, the hypocotyl arch raised, and the radicle $10-\mathrm{mm}$ long. Total germination was calculated as the percent of viable seeds producing normal seedlings after 30 days. Germination rate was calculated as days to $50 \%$ of 30 -day germination.

\section{Statistical Analyses}

Effects of planting date, seedbed environment, and seed source on seed water content, viability, total percent germination, days to $50 \%$ germination, and seedling survival and height were evaluated by analyses of variance. Germination and viability data were transformed for analysis using the arcsin transformation (Snedecor and Cochran 1980). The square root transformation was used to normalize seedling counts. Data were analyzed separately by year, planting site, and seed-recovery or seedling-count date due to differences in planting dates between years and sites. Means were separated by Fisher's least significant difference. All differences reported are significant at $P \leq 0.05$. Means and standard errors were calculated for seedling heights $(\bar{x} \pm \mathrm{SE})$. Regression analyses were used to explain the relationship between collection date and total and rate of germination.

\section{Results}

\section{Environmental Site Conditions}

1987-1988

Soil temperatures were below $0^{\circ} \mathrm{C}$ at both sites almost continuously until early February (Figs. 1 and 2). Minimum daily soil and air temperatures were below $0^{\circ} \mathrm{C}$ until early March and within the $1-15^{\circ} \mathrm{C}$ range, commonly considered to include the effective prechilling temperatures for many species, until mid June (Figs. 1 and 2).

Precipitation patterns were similar for the 2 sites with December to July precipitation totaling $118 \mathrm{~mm}$ at Birds of Prey and $104 \mathrm{~mm}$ at Reynolds Creek (Figs. 1 and 2). Precipitation was $63 \%$ of the 21-year average at Reynolds Creek. Water status of seedbeds on the 2 sites fluctuated from December through July, but did not exceed $-0.2 \mathrm{MPa}$ on any sampling date (Figs. 1 and 2). Seedbeds were open and exposed to wind throughout much of the winter at Birds of Prey, and water potentials were less than $-1.5 \mathrm{MPa}$ in the surface soil layer on all planting dates (Fig. 1). Late-fall plantings at Reynolds Creek were under snow cover almost continually through mid January. Winter plantings were made as snow melted and surface soils thawed during the day. Surface soils were dry on early-and late-spring planting dates with water potentials less than $-1.5 \mathrm{MPa}$ (Fig. 2).

\section{8-1989}

As in 1987-88, minimum soil and air temperatures were below $0^{\circ} \mathrm{C}$ until early March (Figs. 1 and 2); but were, however, in the $1-15^{\circ} \mathrm{C}$ range until mid to late May. Differences in amount and distribution of precipitation again caused variation in soil water status of seedbeds (Figs. 1 and 2). Birds of Prey received $37 \mathrm{~mm}$ of precipitation from December through February and $37 \mathrm{~mm}$ in March. Reynolds Creek received $51 \mathrm{~mm}$ from December through February and $39 \mathrm{~mm}$ in March. Precipitation in March 1989 exceeded that in March 1988 by $60 \%$ at Birds of Prey and $187 \%$ at Reynolds Creek. Birds of Prey received $19 \mathrm{~mm}$ of precipitation from April through July, $71 \%$ less than in 1988. Reynolds Creek precipitation from April through July totaled $29 \mathrm{~mm}, 43 \%$ lower than in 1988 .

Seedbeds at Birds of Prey were intermittently snow covered from late December until mid January. Surface soil was frozen on the late-fall planting date. Soil on Reynolds Creek seedbeds was frozen and snow covered during much of late December and January. Soil water potential exceeded $-0.08 \mathrm{MPa}$ on the winter, early-spring, and late-spring planting dates at both sites (Figs. 1 and 2).

\section{Seedling Dynamics}

\section{7-1988 Plantings}

Emerging seedlings were first noted on 13 March 1988 at Birds of Prey and 1 March 1988 at Reynolds Creek. Within counting dates at each site, seedling densities were low and similar among planting dates and seed sources. Only seedlings emerging from late-fall plantings survived until June 1988, with densities averaging 1 seedling $\mathrm{m}^{-2}$ at each site. By July 1989 densities decreased to $0 \mathrm{~m}^{-2}$ at Birds of Prey and remained $1 \mathrm{~m}^{-2}$ at Reynolds Creek. Additional seedlings emerged in spring 1989, and by July 1989 densities of newly emerged seedlings averaged $1 \mathrm{~m}^{-2}$ at Birds of Prey and $2 \mathrm{~m}^{-2}$ at Reynolds Creek with no differences detected among seed sources or planting dates. By July 1989, height averaged $4 \pm 0.3 \mathrm{~cm}$ for newly emerged and $15 \pm 1.3 \mathrm{~cm}$ for 1-year old seedlings.

\section{8-1989 Plantings}

Seeds planted in late fall began germinating with embryos 

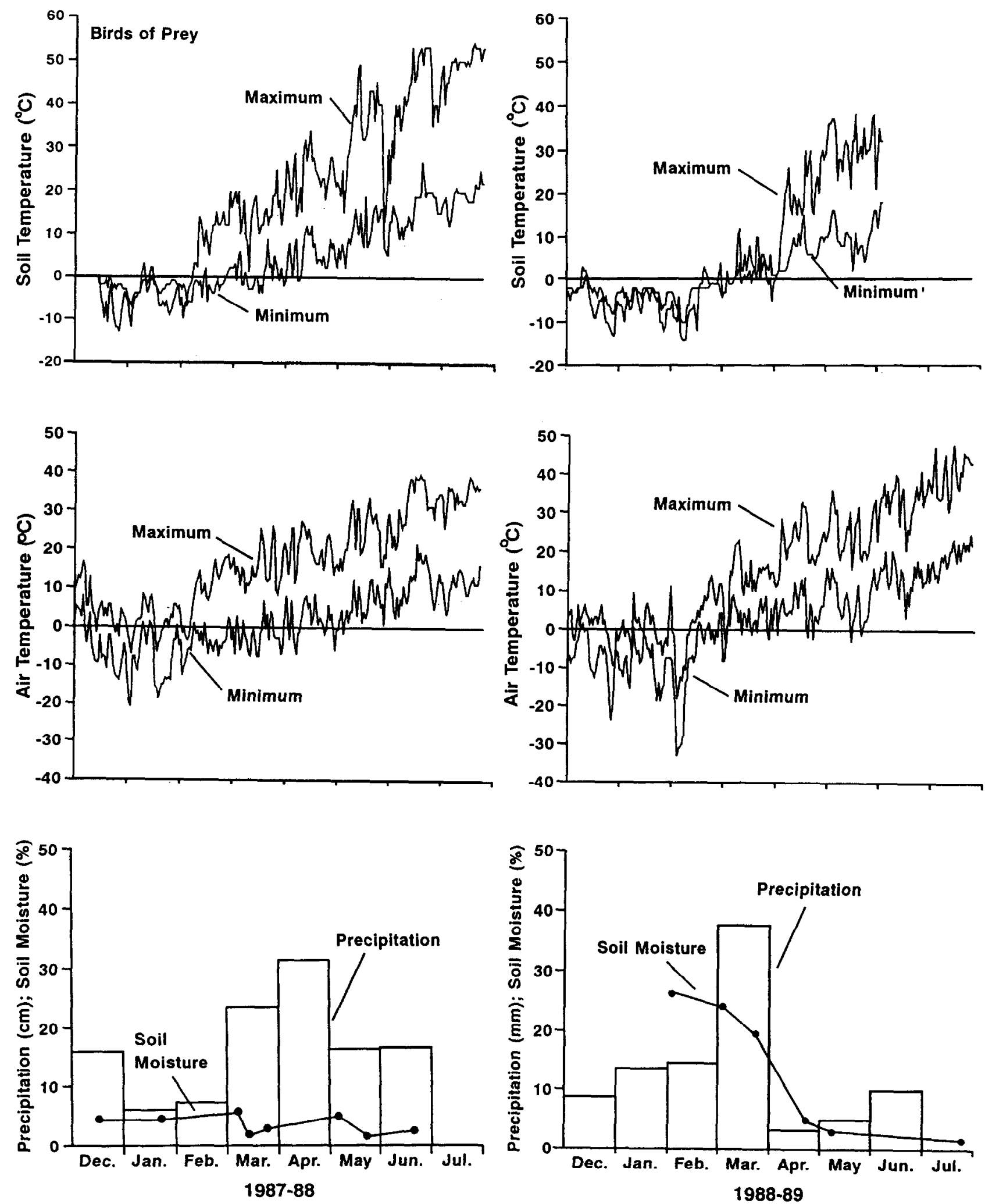

Fig. 1. December to July 1987-88 and 1988-89 soll temperature (0-20-mm depth) and air temperature profiles, precipitation, and soil water (0-30-mm depth) for the Birds of Prey planting site. 

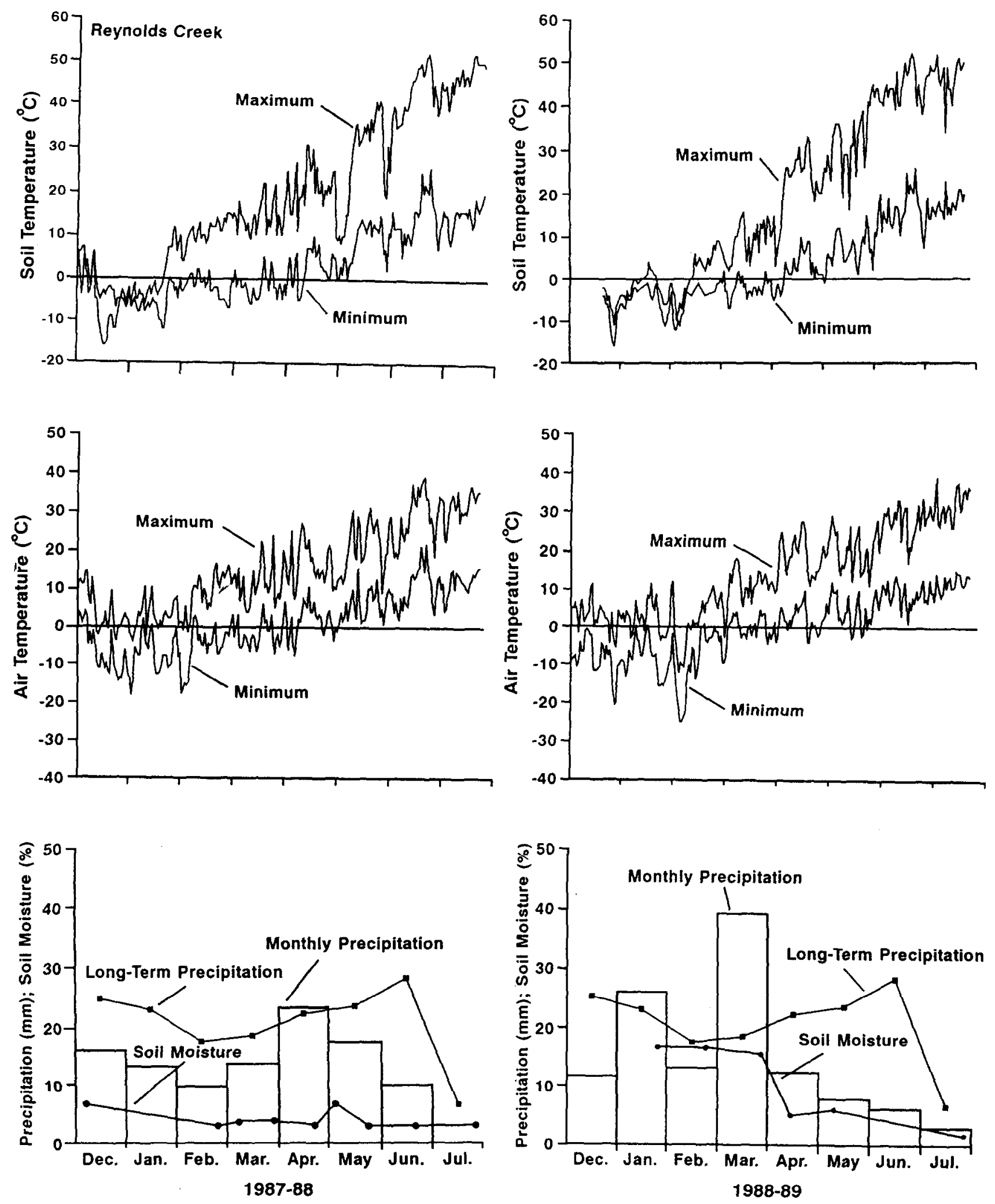

Fig. 2.December to July 1987-88 and 1988-89 soil temperature (0-20-mm depth) and air temperature profiles, precipitation, and soil water (0-30-mm depth) and long-term precipitation (21-year average) for the Reynolds Creek plant site. 
uncoiling in the bags in late February and early March when maximum and minimum air temperatures at the 2 sites averaged 8 and $0^{\circ} \mathrm{C}$ and surface soil temperatures averaged 4 and $-2^{\circ} \mathrm{C}$ (Shaw 1992). Substantial numbers of seedlings emerged from late-fall seedings by 12 March 1989 at Birds of Prey and 11 March 1989 at Reynolds Creek with most seedlings emerging by late March. Maximum and minimum air and surface soil temperatures from 5 March to $25 \mathrm{March}$ averaged 12 and $0^{\circ} \mathrm{C}$ (Table 4). Emergence was greater from late-fall compared to early- or late-spring plantings at each site on all counting dates (Table 4). Many weak and dead seedlings were noted at both sites in early July 1989 (Shaw 1992).

Table 4. Density of spiny hopsage seedlings by counting date, planting date, and 4 seed sources on Birds of Prey and Reynolds Creek 1988-89 plantings, southwestern Idaho.

\begin{tabular}{|c|c|c|c|c|c|}
\hline \multirow[b]{2}{*}{$\frac{\text { Counting date }}{\text { Planting date }}$} & \multicolumn{4}{|c|}{ Birds of Prey } & \multirow{2}{*}{$\begin{array}{c}\begin{array}{c}\text { Reynolds } \\
\text { Creek }\end{array} \\
\text { Seed } \\
\text { source } \\
\text { mean }\end{array}$} \\
\hline & $\begin{array}{c}\text { Reynolds } \\
\text { 1986B }\end{array}$ & $\begin{array}{c}\text { Reynolds } \\
\text { 1988B }\end{array}$ & $\begin{array}{c}\text { Sponge } \\
\text { Springs } \\
1986\end{array}$ & $\begin{array}{c}\text { Sponge } \\
\text { Springs } \\
1988\end{array}$ & \\
\hline $12 \& 11$ Mar. 1989 & \multicolumn{5}{|c|}{$\ldots \ldots \ldots$ No. seedlings $\mathrm{m}^{-2}, \ldots \ldots$} \\
\hline $\begin{array}{l}\text { Late fall-88 } \\
\text { Early spring- } 89\end{array}$ & \multicolumn{4}{|c|}{$\begin{array}{c}60 \mathrm{a}^{1,2} \\
0 \mathrm{~b}\end{array}$} & $\begin{array}{r}13 \mathrm{a} \\
0 \mathrm{~b}\end{array}$ \\
\hline \multicolumn{6}{|l|}{$23 \& 20$ Mar. 1989} \\
\hline $\begin{array}{l}\text { Late fall-88 } \\
\text { Early spring-89 }\end{array}$ & $\begin{array}{c}103 \mathrm{ABa} \\
44 \mathrm{Ab}\end{array}$ & $\begin{array}{c}86 \mathrm{Ba} \\
\Gamma \mathrm{Ab}^{3}\end{array}$ & $\begin{array}{r}114 \mathrm{Aa} \\
0 \mathrm{Ab}\end{array}$ & $\begin{array}{c}109 \mathrm{ABa} \\
4 \mathrm{Ab}\end{array}$ & $\begin{array}{r}39 \mathrm{a} \\
1 \mathrm{~b}\end{array}$ \\
\hline \multicolumn{6}{|l|}{18 \& 11 Apr. 1989} \\
\hline $\begin{array}{l}\text { Late fall-88 } \\
\text { Early spring-89 } \\
\text { Late spring-89 }\end{array}$ & $\begin{array}{r}93 \mathrm{Aa} \\
12 \mathrm{Bb} \\
0 \mathrm{Ac}\end{array}$ & $\begin{array}{r}70 \mathrm{Ba} \\
16 \mathrm{Bb} \\
\mathrm{TAc}\end{array}$ & $\begin{array}{l}88 \mathrm{ABa} \\
32 \mathrm{Ab} \\
\mathrm{TAc}\end{array}$ & $\begin{array}{c}74 \mathrm{ABa} \\
24 \mathrm{Ab} \\
0 \mathrm{Ac}\end{array}$ & $\begin{array}{r}94 \mathrm{a} \\
9 \mathrm{~b} \\
0 \mathrm{c}\end{array}$ \\
\hline \multicolumn{6}{|l|}{ 6\& 3 Jul. 1989} \\
\hline $\begin{array}{l}\text { Late fall- } 88 \\
\text { Early spring- } 89 \\
\text { Late spring- } 89 \\
\text { Mean }\end{array}$ & \multicolumn{4}{|c|}{$\begin{array}{r}51 \mathrm{a} \\
8 \mathrm{~b} \\
\mathrm{Tc}\end{array}$} & $\begin{array}{r}41 \mathrm{a} \\
2 \mathrm{~b} \\
0 \mathrm{~b}\end{array}$ \\
\hline \multicolumn{6}{|l|}{$17 \& 10$ Jul. 1990} \\
\hline $\begin{array}{l}\text { Late fall- } 88 \\
\text { Early spring-89 } \\
\text { Late spring-89 }\end{array}$ & $\begin{array}{c}\text { TBa } \\
0 A a \\
0 A a\end{array}$ & $\begin{array}{l}0 \mathrm{Ba} \\
0 \mathrm{Aa} \\
0 \mathrm{Aa}\end{array}$ & $\begin{array}{l}2 \mathrm{ABa} \\
0 \mathrm{Aa} \\
0 \mathrm{Aa}\end{array}$ & $\begin{array}{l}4 A a \\
0 A b \\
0 A b\end{array}$ & $\begin{array}{r}18 \mathrm{a} \\
1 \mathrm{~b} \\
0 \mathrm{~b}\end{array}$ \\
\hline
\end{tabular}

'Seed source means within counting date, planting date, and planting site followed by similar upper case letters do not differ significantly $(P<0.05)$ using Fisher's least significant difference. Planting date means within counting date, seed source, and study site followed by similar lower case letters do not differ significantly $(P>0.05)$ using Fisher's least significant difference.

${ }^{2}$ Averaged across seed sources.

${ }^{3} \mathrm{~T}=$ less than 0.5 seedlings $\mathrm{m}^{-2}$.

${ }^{4}$ Averaged across planting dates.

Density of established seedlings in July 1989 was 6 times greater on late-fall compared to early-spring plantings at Birds of Prey and 26 times greater at Reynolds Creek (Table 4). July 1989 seedling density of Sponge Springs 1986 and Sponge Springs 1988 sources at Birds of Prey was 1.6 times greater than for Reynolds $1986 \mathrm{~B}$ and Reynolds 1988B sources. Seedling density did not vary among seed sources at Reynolds Creek.

By July 1990 only seedlings developing from llate-fall seedings survived at Birds of Prey (Table 4). At Reynolds Creek seedling density was 18 times greater from late-fall compared to earlyspring plantings. Seedling height averaged $4 \pm 0.5 \mathrm{~cm}$ at Birds of Prey and $8 \pm 0.5 \mathrm{~cm}$ at Reynolds Creek.

\section{Seed Dynamics 1987-1988}

\section{Water Content}

Water content of field-incubated seeds ranged from 17 to $34 \%$ at Reynolds Creek and 29 to $32 \%$ at Birds of Prey, exceeding controls by 70 to $300 \%$ during the first 2 collection dates at Birds of Prey and
Table 5. Total percent germination and days to $50 \%$ germination for 2 spiny hopsage seed sources planted in the field in nylon bags on 3 planting dates and recovered after selected intervals from Birds of Prey and Reynolds Creek 1987-88 plantings, southwestern Idaho.

\begin{tabular}{cccccc}
\hline & \multicolumn{2}{c}{ Birds of Prey } & & \multicolumn{2}{c}{ Reynolds Creek } \\
\cline { 2 - 3 } \cline { 5 - 6 } Recovery Date & & Sponge & & Sponge \\
\cline { 5 - 6 } Planting date & Reynolds & Springs & & Reynolds & Springs \\
\cline { 5 - 7 } & $1986 \mathrm{~A}$ & 1986 & & $1986 \mathrm{~A}$ & 1986 \\
\hline
\end{tabular}

.

Winter-88

Late fall

Control $^{3}$

Mean

$62 \mathrm{a}^{1,2}$

$68 \mathrm{a}$

arly spring- 88

$\begin{array}{lr}\text { Late fall } & 68 \mathrm{Ba} \\ \text { Winter } & 38 \mathrm{Ab} \\ \text { Control } & 6 \mathrm{Bc}\end{array}$

$32 \mathrm{~B}^{4}$

$9 \mathrm{~b}$

$39 \mathrm{~A}$

$9 b$

ate spring-88

Late fall

Winter

Early spring

Control

Mean

Early summer-88

$\begin{array}{lrllll}\text { Late fall } & 32 \mathrm{Ba} & 46 \mathrm{Aa} & & 56 \mathrm{a} & \\ \text { Winter } & 22 \mathrm{Ba} & 42 \mathrm{Aab} & & 47 \mathrm{a} & \\ \text { Early spring } & 11 \mathrm{Bb} & 35 \mathrm{Ab} & & 33 \mathrm{~b} & \\ \text { Control } & 7 \mathrm{Ab} & 11 \mathrm{Ac} & & 9 \mathrm{c} & \\ \text { Mean } & & & 28 \mathrm{~B} & & 44 \mathrm{~A}\end{array}$

Winter-88

94Aa

$83 a$

$41 \mathrm{Ab}$

Bc $\quad 16 \mathrm{Ac}$

32B

$40 \mathrm{~A}$

$88 a$

$47 \mathrm{~b} \quad 50 \mathrm{~b}$

$25 \mathrm{c}$

$12 \mathrm{~d}$

38B

$47 \mathrm{~A}$

- Days to $50 \%$ germination

44A
Late fall

Control

Early spring-88

$\begin{array}{lrr}\text { Late fall } & 6 c & 6 c \\ \text { Winter } & 10 b & 15 b \\ \text { Control } & 19 a & 19 a\end{array}$

$19 \mathrm{a}$

Late spring-88

Late fall

Winter

Early spring

Control

$8 b$

$7 \mathrm{~b}$

$21 \mathrm{a}$

arly summer-88

$\begin{array}{lll}\text { Late fall } & 14 \mathrm{~b} & 13 \mathrm{~b} \\ \text { Winter } & 15 \mathrm{~b} & 13 \mathrm{~b} \\ \text { Early spring } & 17 \mathrm{~b} & 15 \mathrm{~b}\end{array}$

Control

22a

$22 \mathrm{a}$

'Seed source means within planting date, recovery date, and seed characteristic followed by similar upper case letters do not differ significant]y $(P>0.05)$. Planting date means within recovery date and seed source followed by similar lower case letters do not differ significantly $(P>0.05)$.

2 Averaged across seed sources.

'Seeds stored in sealed containers at $3-5^{\circ} \mathrm{C}$.

4 Averaged across planting dates.

the first 3 collection dates at Reynolds Creek. The variability was probably due to infrequent rain showers and differential drying on seedbeds. By early summer, water content declined to $6 \%$ in all field-incubated seeds. Seeds were never fully imbibed on any collection date. Control seeds stored in the laboratory contained $50 \%$ water when fully imbibed at room temperature $\left(21^{\circ} \mathrm{C}\right)$.

\section{Viability}

Field incubation during late fall and winter did not decrease seed viability. A slight decrease in viability (62 compared to $76 \%$ for controls) was noted for Sponge Springs 1986 seeds beginning in 

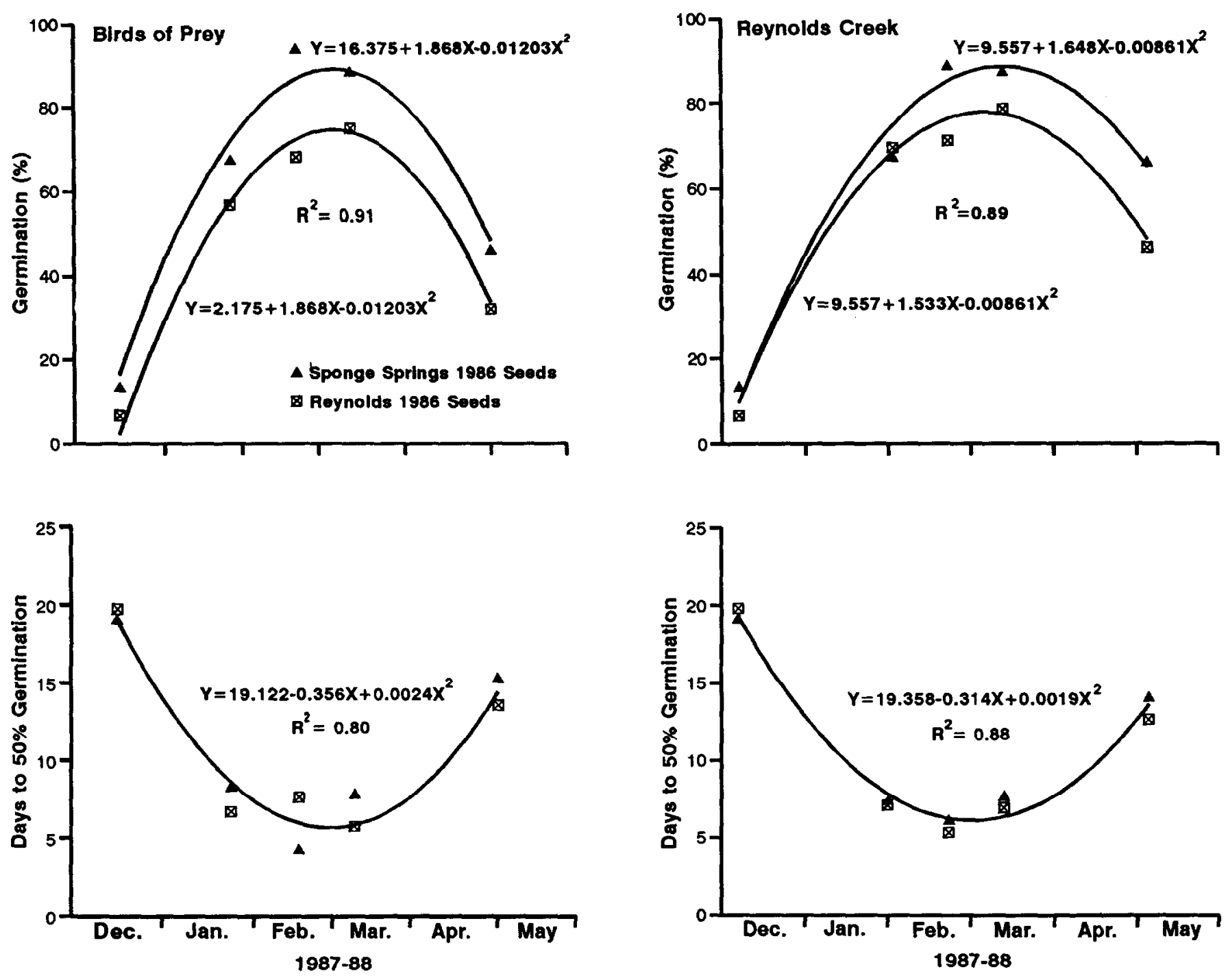

Fig. 3. Germination and germination rate of seeds harvested in 1986 at Reynolds, site A, and Sponge Springs and planted at Birds of Prey and Reynolds Creek in late fall 1987 and recovered on selected 1988 dates.

early spring and continuing into later recovery dates. Viability of late-fall-, winter-, and early- spring-planted seeds of the 2 sources declined to 58,60 , and $63 \%$ by early summer compared to $70 \%$ for controls. Some loss in viability was related to seeds germinating in the bags before recovery. Sponge Springs 1986 seeds were usually more viable than Reynolds Creek 1986A, with significant differences ranging from 5 to $16 \%$.

\section{Germination Total and Rate}

Total germination was substantially improved by field incubation, with longer incubations generally providing the greatest improvement (Table 5). Exceptions were the similarity between controls and winter-planted seeds in early spring at Reynolds Creek, and between late-fall- and winter-planted seeds recovered in early summer at both sites. Reynolds $1986 \mathrm{~A}$ planted at Birds of Prey were the only seeds not responding positively to incubation from early spring to early summer. Sponge Springs 1986 seeds generally germinated better than Reynolds 1986A seeds (Table 5 and Fig. 3). Speed of germination also tended to increase with longer incubations in soil, but rates for winter and early-spring plantings were similar. By summer, germination rates were similar for all planted seeds, and all were greater than rates of controls.
Germination rates did not vary between seed sources (Table 5 and Fig. 3).

\section{Seed Dynamics 1988-1989 \\ Water Content}

Water contents averaged 35 to $44 \%$ at both sites and exceeded controls (6 to $7 \%$ ) on the first 3 recovery dates. In late spring, water content was greater for seeds planted in winter (55\%) compared to early spring ( $44 \%)$. These values reflect recent precipitation and seed coat rupturing of some winter-planted seeds. By early summer, seeds planted in early and late spring contained 10 to $22 \%$ water compared to 6 to $8 \%$ for controls.

\section{Viability}

Viability of seeds planted at Birds of Prey did not decrease relative to controls until early summer 1989 . By this recovery date, viability of seeds planted in early and late spring decreased to $71 \%$ compared to $83 \%$ for controls. Among sources at Reynolds Creek, Reynolds 1988B generally contained the highest percentage of viable seeds, surpassing others by a range of 7 to $13 \%$. Embryos of some Reynolds 1986B and Reynolds $1988 \mathrm{~B}$ seeds planted in winter began uncoiling in the nylon bag by late spring. Viability of nongerminated seeds remaining in these bags on this date $(72 \%$ for 
Table 6. Total percent germination, and days to $50 \%$ germination for 4 spiny hopsage seed sources planted in the field in nylon bags on 4 planting dates and recovered after selected intervals from Birds of Prey and Reynolds Creek 1988-89 plantings, southwestern Idaho.

\begin{tabular}{|c|c|c|c|c|c|c|c|c|}
\hline \multirow[b]{2}{*}{$\frac{\text { Recovery date }}{\text { Planting date }}$} & \multicolumn{4}{|c|}{ Birds of Prey } & \multicolumn{4}{|c|}{ Reynolds Creek } \\
\hline & $\begin{array}{c}\text { Reynolds } \\
\text { 1986B }\end{array}$ & $\begin{array}{c}\text { Reynolds } \\
\text { 1988B }\end{array}$ & $\begin{array}{c}\text { Sponge } \\
\text { Springs } \\
1986\end{array}$ & $\begin{array}{c}\text { Sponge } \\
\text { Springs } \\
1988\end{array}$ & $\begin{array}{c}\text { Reynolds } \\
\text { 1986B }\end{array}$ & $\begin{array}{c}\text { Reynolds } \\
\text { 1988B }\end{array}$ & $\begin{array}{c}\text { Sponge } \\
\text { Springs } \\
1986\end{array}$ & $\begin{array}{c}\text { Sponge } \\
\text { Springs } \\
1988\end{array}$ \\
\hline \multicolumn{9}{|l|}{ Winter-89 } \\
\hline $\begin{array}{l}\text { Late fall } \\
\text { Control }^{3}\end{array}$ & \multicolumn{4}{|c|}{$\begin{array}{c}77 a^{1,2} \\
4 b\end{array}$} & \multicolumn{4}{|c|}{$\begin{array}{r}74 a \\
4 b\end{array}$} \\
\hline $\begin{array}{l}\text { Winter } \\
\text { Control }\end{array}$ & \multicolumn{4}{|c|}{$\begin{array}{r}42 a \\
9 b\end{array}$} & \multicolumn{4}{|c|}{$\begin{array}{r}66 a \\
9 c\end{array}$} \\
\hline Mean & $20 \mathrm{C}^{4}$ & $32 \mathrm{~A}$ & $29 \mathrm{AB}$ & $22 \mathrm{BC}$ & $31 \mathrm{C}$ & $43 \mathrm{~A}$ & $41 \mathrm{AB}$ & $36 \mathrm{BC}$ \\
\hline \multicolumn{9}{|l|}{ Late spring-89 } \\
\hline $\begin{array}{l}\text { Winter } \\
\text { Early spring } \\
\text { Control }\end{array}$ & $\begin{array}{c}23 \mathrm{Ba} \\
7 \mathrm{Ab}\end{array}$ & $\begin{array}{l}33 \mathrm{Ba} \\
12 \mathrm{Ab}\end{array}$ & $\begin{array}{r}\overline{48 \mathrm{Aa}} \\
8 \mathrm{Ab}\end{array}$ & $\begin{array}{r}24 \mathrm{Ba} \\
9 \mathrm{Ab}\end{array}$ & \multicolumn{4}{|c|}{$\begin{array}{r}65 \mathrm{a} \\
36 \mathrm{~b} \\
9 \mathrm{~b}\end{array}$} \\
\hline \multicolumn{9}{|l|}{ Winter-89 } \\
\hline $\begin{array}{l}\text { Late fall } \\
\text { Control }\end{array}$ & \multicolumn{4}{|c|}{$\begin{array}{r}8 a \\
19 a\end{array}$} & \multicolumn{4}{|c|}{$\begin{array}{r}7 b \\
19 a\end{array}$} \\
\hline \multicolumn{9}{|l|}{ Early spring-89 } \\
\hline $\begin{array}{l}\text { Winter } \\
\text { Control }\end{array}$ & \multicolumn{4}{|c|}{$\begin{array}{r}8 b \\
18 a\end{array}$} & \multicolumn{4}{|c|}{$\begin{array}{r}9 \mathrm{~b} \\
18 \mathrm{a}\end{array}$} \\
\hline \multicolumn{9}{|l|}{ Late spring-89 } \\
\hline $\begin{array}{l}\text { Winter } \\
\text { Early spring } \\
\text { Control }\end{array}$ & \multicolumn{4}{|c|}{$\begin{array}{r}8 b \\
21 a\end{array}$} & & & & \\
\hline \multicolumn{9}{|l|}{ Early summer-89 } \\
\hline
\end{tabular}

'Seed source means within planting date, recovery date, and seed characteristic followed by similar upper case letters do not differ significantly $(P>0.05)$. Planting date means within recovery date and seed source followed by similar lower case letters do not differ significantly $(P>0.05)$.

${ }^{2}$ Averaged across seed sources.

3Seeds stored in sealed containers at $3-5^{\circ} \mathrm{C}$

4 Averaged across planting dates.

sWinter planted seeds from Birds of Prey were not analyzed as many seeds had initiated germination in the nylon bags.

WAveraged across seed sources and planting dates.
'Avinter planted seeds from Birds of Prey were not ar

Reynolds 1986B and 59\% for Reynolds 1988B) was lower than the $85 \%$ viability of controls and 10 and $19 \%$ lower than seeds planted in early spring. By early summer, viability of seeds of all sources planted in early and late spring declined to 77 compared to $83 \%$ for controls.

\section{Germination Total and Rate}

The 4 seed sources responded somewhat similarly to seedbed microenvironments (Table 6). Although total germination varied among seed sources in early and late spring at both sites and early summer at Reynolds Creek (Table 6), no clear patterns or trend emerged. Total germination was enhanced by field incubation during late fall, winter, and early spring at both sites. In late spring, seeds planted in winter at Reynolds Creek exhibited greater total germination than seeds planted in early spring, whereas in early summer, total germination of Reynolds $1986 \mathrm{~B}$ and Sponge Springs 1988 seeds planted in early spring and all seeds planted in late spring was slightly enhanced compared to controls. Within planting dates, germination rate did not vary among sources at either site on any recovery date (Table 6). Germination rate was, however, consistently 2 to 3 times faster for field-incubated seeds compared to controls until early summer.

\section{Discussion}

Germinability of spiny hopsage seeds was increased by exposure to cool, moist seedbed environments through late fall and winter. This response permits early-spring emergence and growth if soil water is adequate. Haferkamp et al. (1990) reported late-fall and winter planting favored germination of prostrate kochia (Kochia prostrata [L.] Schrader) exposed to similar conditions in southeastern Oregon.

Some nongerminating seeds may have entered secondary dormancy in response to specific environmental conditions. Evidence for this response is indicated by the seasonal variation in germination percentages of late-fall, winter, and early-spring plantings each year (Fig. 3 and Tables 5 and 6). Total germination typically increased through late spring and declined by early summer. Germination may have decreased in response to high temperatures and inadequate precipitation in April and May or reduced vigor of seeds incubated in soil until early summer. Induction of secondary dormancy in response to high temperatures and water stress was 
reported for Chenopodium bonus-henricus L., an herbaceous chenopod (Khan and Karssen 1980). This mechanism permits seeds to remain viable in soil until conditions favorable for release of secondary dormancy and subsequent germination are encountered. Determining whether spiny hopsage seeds are capable of entering secondary dormancy and affecting factors will require further investigation.

The poor emergence from some early- and late-spring plantings may have resulted from exposure to unfavorable moisture or temperature conditions. Although air and soil temperatures in spring were often in the $0-15^{\circ} \mathrm{C}$ range, seed water content may have been too low for prechilling to be effective. In addition, only a portion of this temperature range may be effective for prechilling spiny hopsage seeds. Short periods of chilling are not cumulative; secondary dormancy may be induced during intermittent high temperature periods (Bewley and Black 1984). Seedling emergence and establishment from early-spring compared to late-fall plantings may also have been reduced as water conditions were less favorable for germination and the period for seedling development prior to summer dormancy was shorter.

Accumulation of seeds in states of primary or secondary dormancy in the soil seed bank could contribute to episodic seedling establishment in good water years as has been reported for spiny hopsage in the Mojave Desert (Wallace and Romney 1972, ElGhonemy et al. 1980). Kay et al. (1988) reported spiny hopsage seeds remained viable in sealed storage at room temperature for 14 years. Longevity of spiny hopsage seeds in the soil has not been examined. Ability of some spiny hopsage seeds to survive in soil beyond the planting year was indicated by limited second- and third-year emergence on Reynolds Creek 1986-87 plantings (Shaw 1992). Frischknecht and Ferguson (1984) reported little first-year germination of spiny hopsage and other chenopods seeded in Utah's Uinta Basin during a drought year. Excellent emergence of some seed sources, however, was noted the second year.

Laboratory germination and germination rate of recovered seeds did not vary consistently between seed sources in this study, possibly because seeds were collected from similar environments (Table 1). Seedling establishment differed between seed sources only on the 1988-89 Birds of Prey planting after 1 growing season. Others, however, have reported variation in germination characteristics among populations of spiny hopsage (Wood et al. 1976), spineless hopsage (Grayia brandegei Gray) (Meyer and Pendleton 1990), and shadscale (Sanderson et al. 1990) from more diverse environments.

Seed age did not appear to affect laboratory germination or cause consistent differences in field germination at the 2 locations in 1988-89. Dry afterripening has been reported to improve germination of several chenopod shrubs (Smith 1974). Pendleton and Meyer (1990) reported laboratory germination of spineless hopsage was improved by 2 years of dry afterripening at room temperature. King (1947) found 6-year old spiny hopsage seeds from eastern Washington required a shorter moist-prechill than 4-year old seeds.

Results of this study show that late-fall or early-winter planting is necessary to expose seeds to cool, moist seedbeds and maximize early-spring germination and emergence during years when adequate soil water is available. Germination and emergence during this period would allow young seedlings to avoid variable, often stressful environmental conditions, that occur with cyclic wetting and drying of the soil in late spring and early summer.

\section{References}

Ackerman, T.L. 1979. Germination and survival of perennial plant species in the Mojave Desert. The Southwestern Natur. 24:399-408.
Assoc. Off. Seed Anal. 1970. Tetrazolium testing handbook for agricultural seeds. D.F. Grabe (ed.). Assoc. Off. Seed Anal. Handb. 29. Assoc. Off. Seed Anal.

Beatley, J.C. 1979/80. Fluctations and stability in climax shrub and woodland vegetation of the Mojave, Great Basin and transition deserts of southern Nevada. Israel J. Bot. 28:149-168.

Bewley, J.D., and M. Black. 1984. Seeds: physiology of development and germination. Plenum Press, N.Y.

Blaisdell, J.P., and R.C. Holmgren. 1984. Managing Intermountain rangelands-salt-desert shrub ranges. USDA Forest Serv. Gen. Tech. Rep. INT-163. Ogden, Ut.

Collett, R.A. 1980. Soil survey of Ada County area, Idaho. USDA-SCS, Washington, D.C.

Daubenmire, R. 1978. Plant geography with special reference to North America. Academic Press, N.Y.

El-Ghonemy, A.A., A. Wallace, and E.M. Romney. 1980. Frequency distribution of numbers of perennial shrubs in the northern Mojave Desert. Great Basin Natur. Mem. 4:34-38.

Frischknecht, N.C., and R.B. Ferguson. 1984. Performance of Chenopodiaceae species on processed oil shale, p. 293-297. In: A.R. Tiedemann, E.D. McArthur, H.C. Stutz, R. Stevens, and K.L. Johnson (compilers). Proc. Symp. on the Biology of Atriplex and Related Chenopods; 2-6 May 1983; Provo, Ut.; USDA Forest Serv. Gen. Tech. Rep. INT-172. Ogden, Ut.

Glazebrook, T.B. 1941. Overcoming delayed germination in the seed of plants valuable for erosion control and wildlife utilization. M.S. Thesis. Univ. Idaho, Moscow.

Haferkamp, M.R., D.C. Ganskopp, K.L. Marietta, and B.W. Knapp. 1990. Environmental influences on germination of utricles and seedling establishment of 'immigrant' forage kochia. J. Range Manage. 43:518-522.

Kay, B.L., W.L. Graves, and J.A. Young. 1988. Long-term storage of desert shrub seed. Mohave revegetation notes 23. Univ. California, Davis.

Khen, A.A., end C.M. Karssen. 1980. Induction of secondary dormancy in Chenopodium bonus-henricus $\mathrm{L}$. seeds by osmotic and high temperature treatments and its prevention by light and growth regulators. Plant Physiol. 66:175-181.

King, J.E. 1947. The effect of various treatments to induce germination of seeds of some plants valuable for soil conservation and wildlife. M.S. Thesis. Univ. Idaho, Moscow.

Krysl, L.J., B.F. Sowell, M.E. Hubbert, G.E. Plumb, T.K. Jewett, M.A. Smith, and J.W. Waggoner. 1984. Horses and cattle grazing in the Wyoming Red Desert. II. Dietary quality. J. Range Manage. 37:252-256.

Manning, S.J., and D.P. Groeneveld. 1990. Shrub rooting characteristics and water acquisition on xeric sites in the western Great Basin, p. 238-244. In: E.D. McArthur, E.M. Romney, S.D. Smith, and P.T. Tueller (compilers). Proc. Symp. on Cheatgrass Invasion, Shrub Die-off, and Other Aspects of Shrub Biology and Management; 5-7 April 1989; Las Vegas, Nev.; USDA Forest Serv. Gen. Tech. Rep. INT-276. Ogden, Ut.

McCullough, D.R.1969. The Tule elk-its history, behavior, and ecology. Pub. in Zoology 88. Univ. California Press, Berkeley.

Meyer, S.E., and R.L. Pendleton. 1990. Seed germination biology of spineless hopsage: between population differences in dormancy and response to temperature, p. 187-192. In: E.D. McArthur, E.M. Romney, S.D. Smith, and P.T. Tueller (compilers). Proc. Symp. on Cheatgrass Invasion, Shrub Die-off, and Other Aspects of Shrub Biology and Management; 5-7 April 1989; Las Vegas, Nev.; USDA Forest Serv. Gen. Tech. Rep. INT-276. Ogden, Ut.

National Oceanic and Atmospheric Administration. 1987-89. Climatological data, Idaho. Vols. 90-92. Asheville, N.C.

Oregon Water Resources Board. 1969. Oregon's long-range requirements for water. Appendix I-10. General soil map report with irrigable areas, Malheur River drainage basin. Oregon Agr. Exp. Sta., Corvallis.

Pendleton, R.L., and S.E. Meyer. 1990. Seed germination biology of spineless hopsage: inhibition by bract leachate, p. 181-186. In: E.D. McArthur, E.M. Romney, S.D. Smith, and P.T. Tueller (compilers). Proc. Symp. on Cheatgrass Invasion, Shrub Die-off, and Other Aspects of Shrub Biology and Management; 5-7 April 1989; Las Vegas, Nev.; USDA Forest Serv. Gen. Tech. Rep. INT-276. Ogden, Ut.

Rickard, W.H., and M.C. McShane. 1984. Demise of spiny hopsage shrubs following summer wildfire: an authentic record. Northwest Sci. $58: 282-285$.

Sanderson, S.C., H.C. Stutz, and E.D. McArthur. 1990. Geographic differentation in Atriplex confertifolia. Amer. J. Bot. 77:490-498. 
Shaw, N.L. 1992. Germination and seedling establishment of spiny hopsage (Grayia spinosa [Hook.] Moq.). Ph.D. Diss. Oregon State Univ., Corvallis (Diss. Abstr. 9229768).

Shaw, N.L., and M.R. Haferkamp. 1990. Field establishment of spiny hopsage, p. 193-199. In: E.D. McArthur, E.M. Romney, S.D. Smith, and P.T. Tueller (compilers). Proc. Symp. on Cheatgrass Invasion, Shrub Die-off, and Other Aspects of Shrub Biology and Management; 5-7 April 1989; Las Vegas, Nev.; USDA Forest Serv. Gen. Tech. Rep. INT-276. Ogden, Ut.

Smith, J.G. 1974. Grayia Hook. \& Arn. Hopsage, p. 434-436. In: C.S. Shopmeyer (tech. coord.). Seeds of woody plants in the United States. Agr. Hanb. 450, USDA. U.S. Gov. Print. Off., Washington, D.C.
Snedecor, G.W., and W.G. Cochran. 1980. Statistical methods. 7th ed. The Iowa State Univ. Press, Ames.

Stephenson, G.R. 1977. Soil-geology-vegetation inventories for Reynolds Creek Watershed. Univ. Idaho Agr. Exp. Sta., Moscow.

USDA-SCS. 1968. Management and uses of spiny hopsage in the State of Washington. Plant Science Handb. USDA-SCS, Spokane.

Wallace, A., and E.M. Romney. 1972. Radioecology and ecophysiology of desert plants at the Nevada Test Site. USAEC TID-25954. Univ. California, Riverside.

Wood, M.K., R.W. Knight, and J.A. Young. 1976. Spiny hopsage germination. J. Range Manage. 29:53-56. 